\title{
DEVELOPMENT OF THE SCHOOL AS MULTIFUNCTIONAL COMMUNITY RESOURSE IN LATVIA: OPPORTUNITIES AND CHALLENGES
}

\author{
Aija Tūna \\ Initiative „Change Opportunities for Schools”, \\ Soros Foundation - Latvia (SFL)
}

\begin{abstract}
In the context of rapid changes in the society schools face the problem of how to provide services in a way which promotes lifelong learning, social cohesion and sustainable development for individuals and communities while being efficient and accountable. The impact of the financial crises, declining number of students and uncertainty about rural development in general has put small rural schools in Latvia in a challenging situation. Since 2009 the initiative has been implemented to support schools to develop into multifunctional community centres by expanding their functions and reconsidering their role in local communities. The results of the study conducted on the bases of this initiative demonstrate significant potential of community school approach and also reveal challenges in understanding and implementing such approach.
\end{abstract}

Keywords: school as a multifunctional community resource centre, community school, extended functions of school, lifelong learning, civic participation, education policy

\section{Introduction}

In the current situation in Latvia development and strengthening of rural communities and discussion about the role of the school in these communities is very crucial. Looking for the new ways for sustaining schools in rural communities which means providing access to formal education and services of lifelong learning is also very much in-tack with the strategic directions set by the government (Latvija 2030, 2010; Izglītības politikas pamatnostādnes, 2013; Deklarācija, 2014 etc.). Balanced regional development is a precondition for access to education and diverse services for families with children and other groups of local people. In addition, support for increasing social and civic participation is crucial for those living in the rural communities and having vulnerable backgrounds and conditions because of long-term unemployment, lack of skills, age, special needs and other factors. Education in general and school as community resource possess enormous potential and can play crucial role in this ecosystem based on the concept of lifelong learning as necessity of the $21^{\text {st }}$ century.

Since 2009, when a global financial crisis hit Latvia and existence of schools, especially schools with less than 100 students in rural areas were endangered, the initiative "Schools as Community Development Centres" has been implemented embracing approximately 100 schools from all the regions in

\footnotetext{
${ }^{1}$ Initiative has been funded by the Emergency Funds of the Open Society Foundation and implemented by the Soros Foundation - Latvia.
} 
Latvia $^{2}$. The initiative was intended as immediate support to schools in order to maintain their functioning but it also has been very instrumental in two other ways: 1) developing models for new approach to the role and functions of the rural schools in Latvia and 2) as a case for theoretical and empiric studies of transformations in the schools and communities as well as in their relationships. The goal of the paper is to present the initial results of the study on how the small schools in Latvia go through the process of transformation into multifunctional community centres and what challenges they face in order to discover potential of the new type of interactions among the school and diverse stakeholders in the surrounding community.

The author of the paper has been leading the implementation, monitoring and evaluation of the initiative having regular, close and open contacts with involved stakeholders: school administrators, teachers, parents, municipality and civil society representatives, other community members. Empirical data for the study was collected during $2009-2013$ in two surveys conducted in cooperation with the Baltic Institute of Social Studies and summarized in the evaluation reports of the project implementation (BISS, SFL, 2010, 2013). 52 and 41 schools/municipalities were included in the surveys. Obtained data allowed monitoring changes in the involved schools and communities and identify both challenges and potential for sustainability of the results of the initiative. The study also includes data from analyses of diverse documents, such as project proposals and reports submitted by participating schools, protocols of the mentoring visits, articles written by the project participants etc., as well as narratives from numerous school visits and discussions with teachers, school administrators, municipality representatives and people from the communities. Some findings and conclusions about the results and further potential of the school as community resource and development centre are presented in the paper.

\section{Lifelong learning, a community and the functions of a school}

The concept of lifelong learning has become an integral part of the modern vision about successful contemporary life and the role of education in it. In 1970 the concept of a "learning society" was put forward within the UNESCO network encouraging countries across the world to reorganize their education systems by encouraging all agencies to become providers of education and all the citizens to engage in learning, taking full advantage of the opportunities provided by learning societies (Osborne et al, 2013). In many international projects and initiatives across the world emphases have been put on urban environment. This idea goes back to Plutarch's idea that ,the City is the best teacher". Advocates of the potential of the learning cities in the 21st century argue that cities ,do indeed contain immense educational potential - with their

\footnotetext{
${ }^{2}$ See the map with the involved schools at www.parmainuskolas.lv
} 
social and administrative structures and their cultural networks --- also because they constitute a school for civic sentiment and fellow feeling (Faure et al. 1972: 162).

Meanwhile, in the description of the learning society the concept of the community is very essential at any level - regional, city, rural - as a country's learning society can be built only province by province, city by city, and community by community (UIL 2013) as this is where real action and interaction take place. Following this logic it can be said that any community entails powerful potential for learning at any age, for any member of the society and, vice versa, vitality of a community and potential of its development is influenced by values, competences and virtues of each member of the community. The question is what is the role of a school - as an administrative unit, organization, intellectual and physical resource in the community, traditionally providing mainly or exclusively formal education in this framework? Does a school arrive at a need to introduce significant changes in the way it operates and builds relationships with students, families and community members? If yes, why and how?

According to the functionalists theory (e.g., Durkheim E., Parsons T., Ballantine J.), the main functions which education serves in the society include 1) teaching children to be productive members of society, 2) socialization for personal and social development, 3) selection and training of individuals for positions in the society, 4) promoting change and innovation, and 5) fulfilling latent functions of education, such as "unintended, unorganized, informal consequences of the educational process (Ballantine, Spade, 2008:10-11). In order to accomplish these tasks schools have to establish, maintain and improve links with wider society outside the school. In reality schools operate as rather self-sufficient entities without sharing their resources (intellectual and physical) with community and rarely benefitting from community's resources in achieving goals set by curricula.

\section{Dilemma for rural schools: to change or to vanish}

Recent global financial crises has stimulated the discussion on how to assess the school effectiveness and the quality of its results, balancing economic indicators with humanistic pedagogy and rights to have access to education. In rural Latvia schools with relatively small number of students have been traditionally widely spread but with emphases on economic indicators they have been seen "expensive". Even more, with the recent changes in national funding model, increased migration, demographic gap and impact of the financial crises with severe cut in education spending situation of small schools have became extremely critical and for municipalities it is more and more difficult to maintain schools. After the wave of closings in $2008-2009$ according to the public data in school year 2013/14 approximately one third of all schools in Latvia has less 
than 100 students, most of them (255) are situated in small settlements in the rural area.

The aim of the SFL initiative "Schools as Community Development Centres" was to facilitate sustainable transformation of schools into multifunctional community resource centres thus maintaining their typical functions (providing formal education) and expanding activities in order to use existing resources and contribute to development of the local society. The initiative is known in Latvia under the title "Change Opportunities for Schools" which describes very well the context and approach to the actions. Interventions aim at supporting schools, local communities and civil society in developing models for transforming schools into multifunctional community resource centres. The aim has been to promote using small schools as educational, culture and social support centres and encouraging municipalities and local communities to see intellectual and physical resource of local schools in the context of regional development which can provide a range of services relevant to the needs of local communities and promote the development of entrepreneurship.

The idea of a school as a community centre is well know in different countries. While called in different terms, such as community schools (Campbell-Allen et al, 2009), full-service schooling (Dryfoos 1994; Smith, 2000, 2004), extended schools (Extended Schools, 2006), integrated services (Press et al, 2011; Tayler et al, 2008) community schools share common features and role in the community - they are ,full service neighbourhood hubs where the school and partners from across the community come together to make sure children and families have what they need to be successful - in school and in life" (Geiser et al, 2013). In that sense community schools come very close to the concept of learning communities described by the Canadian educationalist Ron Faris as "neighbourhoods, villages, towns, cities or regions that explicitly use lifelong learning as an organizing principle in order to promote collaboration of their civic, economic, public, voluntary and education sectors to enhance social, economic and environmental conditions on a sustainable, inclusive bases (Faris, 2007).

Despite the fact that historically schools in Latvia have been the centre of local communities this experience had been lost and had to be re-introduced. As expressed in many interviews traditionally there is a perception in the society that school is for formal education; in many cases parents are rather reluctant to go to school as it may entail unpleasant conversations. Other community members do not see any reason why to go to the school. On the other hand regulations and practice in schools are based on the assumption that school is for teachers and students, access to premises and infrastructure is restricted according to direct teaching-learning process and entirely controlled by school administration and teachers. As a result it means that the local community has little information about the school, resources are not used effectively and in the situation of scarce finances it seems very expensive to maintain the school. 
Wherewith the first task for schools involved in the initiative was to open the doors for local community, both physically and in a figurative sense which required serious changes in perception on both sides.

\section{From „saving schools” to developing communities}

As analyses of the submitted grant proposals reveal in the first period of the initiative the main concern of the applicants (schools together with municipalities) was to safeguard the very existence of the school and preserve jobs for teachers as it would be very difficult for them to find another qualified job nearby. Expanding functions of the school were mostly perceived as offering afterschool and extra curriculum, the so called interest education for students, mostly from younger grades as well as organizing cultural events and creative workshops (see more at Skola atver durvis, 2010). According to the first survey from 52 respondents/involved schools 45 provided extracurricular activities for students, 43 started to offer activities for adults, mainly in the form of workshops for leisure time in areas where teachers felt comfortable ("what we/school can offer"), in 41 case special events were organized by schools with more participation from local community as before. As for the groups of involved people in 48 cases they were students enrolled in the school, $30-$ preschool age children, 40 - retired people (who turned out to be an active and interested group), 28 - people with low social skills, 28 - single parents etc (BISS, SFL, 2011).

Comparing the evaluation results of the first and second period of the initiative it can be asserted that local communities, schools and municipalities' understanding of the role and potential of the school as a multifunctional community centre (diversifying activities within the school based on the needs assessment, organizing activities in coordination with other local agents, more efficient use of resources etc.) has deepened. Local people are becoming more active demand drivers for a community school. Schools in their turn have become aware of the role of local people needs in expanding the activities of a school and are able to provide a suitable offer for each specific area and community (BISS, SFL, 2013). Local governments have gained assurance based on school activities that a small rural school nowadays can work differently so that, unlike the traditional school model, the school does not only perform formal education functions in a municipality. Methodological framework has been disseminated at the national level (Tuna, 2011) as an opportunity for all schools and municipalities to adopt experiences according to each specific situation.

Involved schools became more aware that in order to expand their functions the school must develop cooperation and build partnership with other players or agents in the community - houses of culture, community centres, libraries, local NGOs, the parish administration and district municipality, entrepreneurs, local farmers etc. According to the survey in the second period in 22 from 30 schools 
involved in the initiative since 2009 resources of schools are now used by NGOs, in 21 case - by non-formal groups of local people, in 18 - by cultural centres, 9 - by local libraries, etc (BISS, SFL, 2013). More diverse participants of the activities are also present. The cooperation is a precondition for combining local resources to address common challenges and improve the quality of life. The model shows that a school is best placed to assume the coordinating role for these inter-institutional networks while any other participants in this network can become coordinators as well - it can be either parish administration, library or community house. The most decisive point is to have shared understanding of the goals of a community school and agreement on the most efficient way to reach the goals.

This was also admitted by municipalities that extended activities of schools have helped even the municipality "better understand what schools do and what can their contribution to the community be". From 35 involved municipalities (on novadi as administrative unit level) 13 fully agree and 16 rather agree that the understanding has improved. It has been mentioned that using building and technical resources of the school for different purposes creates economy of spending for municipality as existing infrastructure is used more efficiently, there is also potential for more effective use of human resources etc. In 16 cases representatives of the municipalities fully agree that the school has become a better support for the municipality, in 18 cases - they rather agree; only one response was difficult to say. What is also important that the school does not compete with other existing structures as it sometimes has been mentioned in public discussions; all respondents from 35 municipalities either fully rejected (26) or rather rejected (9) the statement that the school as a multifunctional centre emerges as a competitor for other local services.

From the schools' perspective support from municipalities in fulfilling new functions has been provided in the forms of $(\mathrm{N}=41$, several answers possible) maintaining premises for diverse activities (38), providing transport not only for students' needs (33), collaboration in developing project proposals (34), providing informative support (29), regular meetings and communication among the school and municipality (32), collaboration on strategic planning regarding local community and school as a multifunctional centre (23), providing administration and book-keeping (21) etc. This can be considered as a positive move towards more substantial cooperation among schools and municipalities for building bases for learning society for common benefit and promoting the role of education as it can be expected to help to foster the desire to live together, which is a basic component of social cohesion and national identity (Delors, 1996).

The many facets of evaluation of the school-municipality-community performance and cooperation within the initiative has suggested that transformation of the school into a multifunctional community centre has asserted itself in practice as a social and educational innovation with high 
potential. Despite the differences between small rural schools, different social contexts they work in, different available resources of all kinds and diverse local community needs all the schools are platforms for empowerment of local communities' (including students') abilities, possibilities and choices in rural environment, thus promoting the development of the territories and improving the life quality in the country. In Latvia emerging community schools do not possess universal functions and characteristics but are open and flexible models according to the local context and needs.

\section{Conclusions}

Supporting schools in returning to their deeper function - to be the centre for development and growth of the community - is significant contribution to lifelong learning opportunities for local people in the context of the $21^{\text {st }}$ century which results into increased wellbeing and quality of life. Schools can play exceptional role in promoting social cohesion as they are close to people with their real needs and can reach almost all the people through families, neighbourhood links etc.

Significant changes have started in the organizational culture of schools themselves as they are starting to reconsider their role in the local community and have discovered opportunities to engage in multifaceted cooperation as well as have realized what benefits there are from such activities for formal learning, fulfilling educational goals and mission. Schools have started to realize that they have human resources, infrastructure and equipment which allow implementing wider functions, serving diverse groups of population and raising civic participation.

It can be concluded that the schools involved in the initiative can be considered as implementers of the pilot projects for small schools' policy and their experience can be used by other schools and for further development of the policy at the national level. Based on the gained experience and studies number of further tasks can be suggested on both, local and national levels as for the time being there is still insufficient political and financial support to such transformation (which largely determines the sustainability of new models) and also insufficient understanding of school's potential from all involved actors. The following aspects should be taken into consideration and improved:

- in order to achieve systemic and sustainable changes and become a multifunctional community centre a school has to engage in the process of change as an organization, not as individual teachers implementing a project, improving communication with community and designing activities based on the specific needs and interests of local people;

- raising further awareness about the school as intellectual and physical resource of the community providing opportunities to access and utilize 
these resources more efficiently by all community members is necessary on all levels;

- changes in policies and normative base is needed to allow schools to receive and manage not only education budget but together with diversified functions (adult education, social and health support, entrepreneurship etc.) run funding from different sources of income;

- in providing grants contribution to infrastructure and equipment should be balanced with available funds for human resources in order to avoid "the syndrome of closed doors" - renovated premises (libraries, youth and NGO centres etc.) without staff;

- improved coordination of functions and resources and cooperation among sectors (education, culture, health, social services) on municipality, as well as national level is needed in order to avoid duplication and gaps.

As well as in many other countries schools as community resource centres in Latvia have extensive potential to foster development of learning communities meeting needs and contributing to the development of communities, especially in the small rural settlements within the framework of lifelong learning. At the same time improved understanding on the part of all stakeholders and changes in the policies are still needed to move from pilot project to systemic solution.

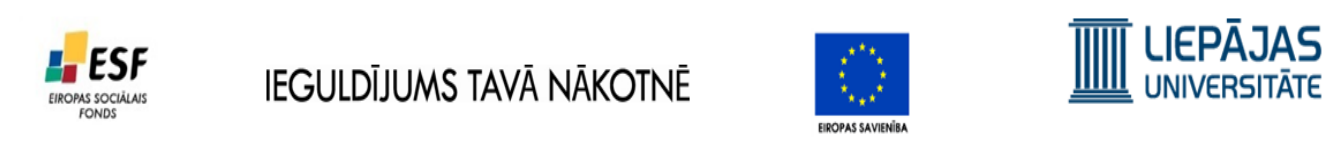

Šis raksts sagatavots ar Eiropas Sociālā fonda atbalstu projektā ,Atbalsts doktora studijām Latvijas Universitātē"

\section{References}

1. Ballantine J.H., Spade J.Z. (2008). Schools and Society: A Sociological Approach to Education. Pine Forge Press

2. Baltic Institute of Social Sciences (2011). Pētijums: Sorosa fonda-Latvija iniciatīvas „Pārmainu iespēja skolām” ietekmes novêrtējums. (In English: Impact evaluation of the SFL intiative "Change opportunities for schools). Retrieved from http://www.sfl.lv/upload_file/2011\%20gads/Parmainu_skolas_ietekmes_novertejums. pdf

3. Baltic Institute of Social Sciences (2013). Pētijums: Sorosa fonda-Latvija iniciatīvas „Pārmainnu iespēja skolām” 2. kārtas „Skola kā kopienas attīstības resurss" novêrtējums. (In English: Evaluation of the second stage "School as community development resource" of the SFL initiative "Change opportunities for schools"). Rīga: SFL, 2013 [unpublished research study report].

4. Latvijas Republikas Ministru Kabinets (2014). Deklarācija par Laimdotas Straujumas vadìtā Ministru kabineta iecerēto darbību. Retrieved from http://www.mk.gov.lv/ lv/mk/darbibu-reglamentejosie-dokumenti/Straujumas-valdibas-deklaracija/

5. Delors J. (1996). Learning: The Treasure within. Report to UNESCO of the International Commission on Education for the Twenty-first Century. Retrieved from http://www.unesco.org/education/pdf/15_62.pdf 
6. Faris R. (2007). Learning communities: Webs of life, literacy and learning. Presentation delivered in Halifax at the Symposium on Learning Communities. October. Retrieved from http://www.ns.literacy.ca/symposium/workshop.htm

7. Faure E., Herrera F., Kaddoura A.-R., Lopes H., Petrovsky A.V., Rahnema M., Ward F.C. (1972). Learning to be: The world of education today and tomorrow. The Report to UNESCO of the International Commission on the Development of Education. Paris/London: UNESCO/Harrap.

8. Geiser, K.E., Kwesi Rollins S., Gerstein A., Blank M. J. (2013). Early Childhood Community School Linkages: Advancing a Theory of Change. Coalition for Community Schools, Institute for Educational Leadership. Retrieved from http://www.communityschools.org/assets/1/AssetManager/ECCSLinkagesTOCReport .pdf

9. LR Izglītības un zinātnes ministrija (2013). Izglìtības attīstības pamatnostādnes 2014.2020.gadam. (In English: Education policy strategy 2014-2020.) Retrieved from http://izm.izm.gov.lv/upload_file/2013/IAP_2020_projekts_pa.pdf

10. Latvija 2030. Latvijas ilgtspējīgas attīstības stratēgija līdz 2030. gadam (2010). (In English: Strategy for Sustainable development of Latvia until 2030) Retrieved from http://www.pkc.gov.lv/images/LV2030/Latvija_2030.pdf

11. Osborne M., Kearns P., Yang J. (2013). Learning cities: Developing inclusive, prosperous and sustainable urban communities. - International Review of Education. (2013) 59: 409 - 423.

12. Skola atver durvis. SFL iniciatīvas "Pārmainun iespēja skolām" projektu pieredzes kräjums. (2010). (In English: The Schools opens the Doors. Collection of practices of the projects in the SFL initiative "Change opportunities for Schools.) Retrieved from http://www.scribd.com/doc/189558989/Skola-atver-durvis-SFL-iniciat\%C4\%ABvasP\%C4\%81rmai\%C5\%86u-iesp\%C4\%93ja-skol\%C4\%81m-projektu-pieredzes$\mathrm{kr} \% \mathrm{C} 4 \% 81$ jums

13. Tūna A (2011). Pašu skola pašu valdībā. Iespējamie darbības virzieni skolas ilgtspējīgai darbībai pašvaldībā. (In English: Own School in Own Governance. Possible directions for sustainable operation of the school in the municipality.) Retrieved from http://parmainuskolas.lv/wp-content/uploads/2011/11/Pasu-skolavaldiba_web.pdf

14. UIL (ŪNESCO Institute for Lifelong Learning). (2013). Terms of Reference for Establishing the International Platform for Learning Cities. Hamburg: UNESCO Institute for Lifelong Learning.

Doctoral student of the University of Latvia

Aija Tūna
Director of the Soros Foundation - Latvia initiative "Change Opportunities for Schools", aija.tuna@gmail.com $+371-29416341$ 